\title{
Primary production and physiological state of phytoplankton at the Ushant tidal front (west coast of Brittany, France)
}

\author{
Christiane Videau \\ Laboratoire de Physiologie Végétale, Université de Bretagne, Occidentale, F-29287 Brest Cédex, France
}

\begin{abstract}
Physical, chemical, and biological parameters relevant to phytoplankton were measured in late summer 1982 across the southern part of the Ushant front. Daily primary production rates (g $\mathrm{C} \mathrm{m}^{-2} \mathrm{~d}^{-1}$ ) increased and assimilation number decreased from the open sea to the frontal zone. However, productivity (mg C $[\mathrm{mg} \mathrm{Chl} \mathrm{a}]^{-1} \mathrm{~h}^{-1}$ ) in the frontal upper layers $(>10 \%$ light surface intensity) was significantly higher than in stratified and transitional waters. Offshore, no dinoflagellates but only nanoflagellates were observed, with diatoms (mainly Nitzschia seriata) in more coastal waters. On spring tides, diatoms were widespread over the transitional area, even on the stratified side. Physiological state of the phytoplankton was assessed on the basis of photosynthetic properties, adenylate energy charge, ATP:Chl a and POC:Chl a ratios, and specific growth rates. Physiological activity of nanoflagellates in well-stratified, nutrient-deplete waters was mainly influenced by light level. Physiological state of the diatom populations was not constant over the transitional area, but in the stratified frontal zone was greater in the upper layer. On the mixed side, by contrast, the physiological state of the phytoplankton was lower, particularly as regards light adaptation.
\end{abstract}

\section{INTRODUCTION}

The Iroise sea, off West Brittany (France), in the northeastern Atlantic, shows a tidal seasonal welldeveloped frontal system, the northern part of which was previously described as the Ushant front (for its physical, chemical and biological properties, see Le Fèvre 1986).

The chlorophyll distribution is similar to other frontal systems described around the British Isles (Holligan \& Harbour 1977, Holligan et al. 1980, Holligan 1981) and elsewhere, with higher values in surface discontinuities or on the thermocline (Le Fèvre et al. 1983). An enhancement of production could be observed in the frontal region, linked to the increase of the chlorophyll values (Pingree et al. 1975, Holligan et al. 1984b). Despite this higher absolute production rate, assimilation numbers and growth rates of phytoplankton in the front appear to be lower than in neighbouring regions (Holligan et al. 1984b, Loder \& Platt 1985). In such a case, the high chlorophyll values observed in the front could only result from a passive phenomenon such as a convergent mechanism.

To evaluate the degree of physical control of biological activity of phytoplankton, specific growth rate was evaluated across the Ushant front. Attention was focused on primary production in relation to the vertical thermal structure of the water masses and the distribution of phytoplankton species.

The adaptation of phytoplankton populations to their environment was also studied, mainly in the frontal boundary. Among the various parameters influencing primary production, we paid particular attention to photoadaptation with regard to species composition, geographical location, and nutrient levels. Photoadaptation described by photosynthesis-irradiance curves is one method of assessing the degree of stability in the water column (Falkowski 1980).

Besides light adaptation and species composition, we investigated whether the physiological state of the phytoplankton could be affected by environmental conditions, namely nutrient levels, by evaluating chemical properties, viz. adenylate energy charge, and $\mathrm{Chl} a$ : ATP and POC: Chl a ratios in the different water types.

\section{METHODS}

During the 'Satir-Dynatlant' cruise (25 Aug to 20 Sep 1982), several hydrographic surveys were carried out 
in the study area to determine the front position. Four reference points located on the $\mathrm{W}$-E transect $48^{\circ} 08^{\prime} \mathrm{N}$ characterizing stratified (S), stratified and mixed transitional ( $F$ and $F^{\prime}$ ), and mixed waters $(M)$ were particularly studied as long-term stations (48 h). The full data are presented by Le Corre \& Mariette (1985).

Daily primary production measurements were made at $1200 \mathrm{~h}$ (sun time) at the ship's location (Fig. 1). At each station, vertical CTD profiles were taken immediatly before and after phytoplankton sampling with a Neil Brown rosette in conjunction with a computer. Phytoplankton samples were collected with Niskin bottles from various light level depths given by a Secchi disc. The water was subsampled for chlorophyll (Turner Model III fluorimeter), and nutrient (Technicon Autoanalyzer II) measurements. Discrete samples were preserved with Lugol iodine solution acid for phytoplankton cell counts.

Primary production was measured by the ${ }^{14} \mathrm{C}$ technique. Duplicate samples from each light level were incubated in $125 \mathrm{ml}$ glass bottles in the presence of $0.148 \mathrm{MBq} \mathrm{NaH}{ }^{14} \mathrm{CO}_{3}$ (C.E.A., France). Samples were incubated on deck for $4 \mathrm{~h}$ under nickel screens simulating in situ light levels. Thermal regulation was ensured by a surface seawater flow $\left(\mathrm{T}=16\right.$ to $18^{\circ} \mathrm{C}$ ). After incubation, each sample was filtered on a $0.8 \mu \mathrm{m}$ Millipore AA membrane and frozen at $-20^{\circ} \mathrm{C}$. After drying, radioactive carbon was assayed by liquid scintillation counting (Picofluor 30 liquid; Packard Tricarb 300 scintillation counter).

Adaptation of the phytoplankton to the light levels sampled was assessed by photosynthesis-irradiance curves. For a given depth, a 2 l sample was incubated with $2.96 \mathrm{MBq} \mathrm{Na}{ }^{14} \mathrm{CO}_{3}$. Triplicate $1 \mathrm{ml}$ aliquots were withdrawn in scintillation liquid to determine total radioactivity; the remainder was subsampled in $100 \mathrm{ml}$ glass bottles and incubated in an artificial light incubator with a surface seawater flow. Subsamples from the same depth were put in a series in the incubator. Two light sources (Cormoran 1500 Mazda) provided from about $2500 \mu \mathrm{E} \mathrm{m}^{-2} \mathrm{~s}^{-1}$ at the first subsample to about $3 \mu \mathrm{E} \mathrm{m} \mathrm{m}^{-2} \mathrm{~s}^{-1}$ at the last one. The photosynthetic available radiation (PAR) was measured with a quantameter Licor LI-185B (400 to $700 \mathrm{~nm}$ ) for each experiment at the site of each bottle. The incubation was conducted over $4 \mathrm{~h}$ with about $1 \mathrm{~h}$ time lag relative to in situ simulated experiments. Subsequent procedure was as above.

ATP content of the particulate fraction was assessed by the luciferin-luciferase method (Karl \& Holm-Hansen 1978). Each sample $(250 \mathrm{ml})$ was filtered through a sterilized. Whatman GF/C Fiber filter $(2.5 \mathrm{~cm} \varnothing)$. The filters were boiled for $5 \mathrm{~min}$ in $3 \mathrm{ml}$ TRIS $0.02 \mathrm{M}$ buffer $(\mathrm{pH}=7.78)$ for extraction of adenine nucleotides, cooled, and preserved at $-25^{\circ} \mathrm{C}$ until measurement which was made with an Interbio C.L.V. ATPmeter.

Adenylate energy charge (AEC) was determined by Atkinson \& Walton's equation (1967):

$$
\mathrm{AEC}=\frac{\mathrm{ATP}+1 / 2 \mathrm{AMP}}{\mathrm{ATP}+\mathrm{ADP}+\mathrm{AMP}}
$$

ADP (adenosine diphosphate) and AMP (adenosine monophosphate) concentrations were deduced from final ATP values obtained after they were transformed to ATP in the presence of pyruvate kinase and myo-

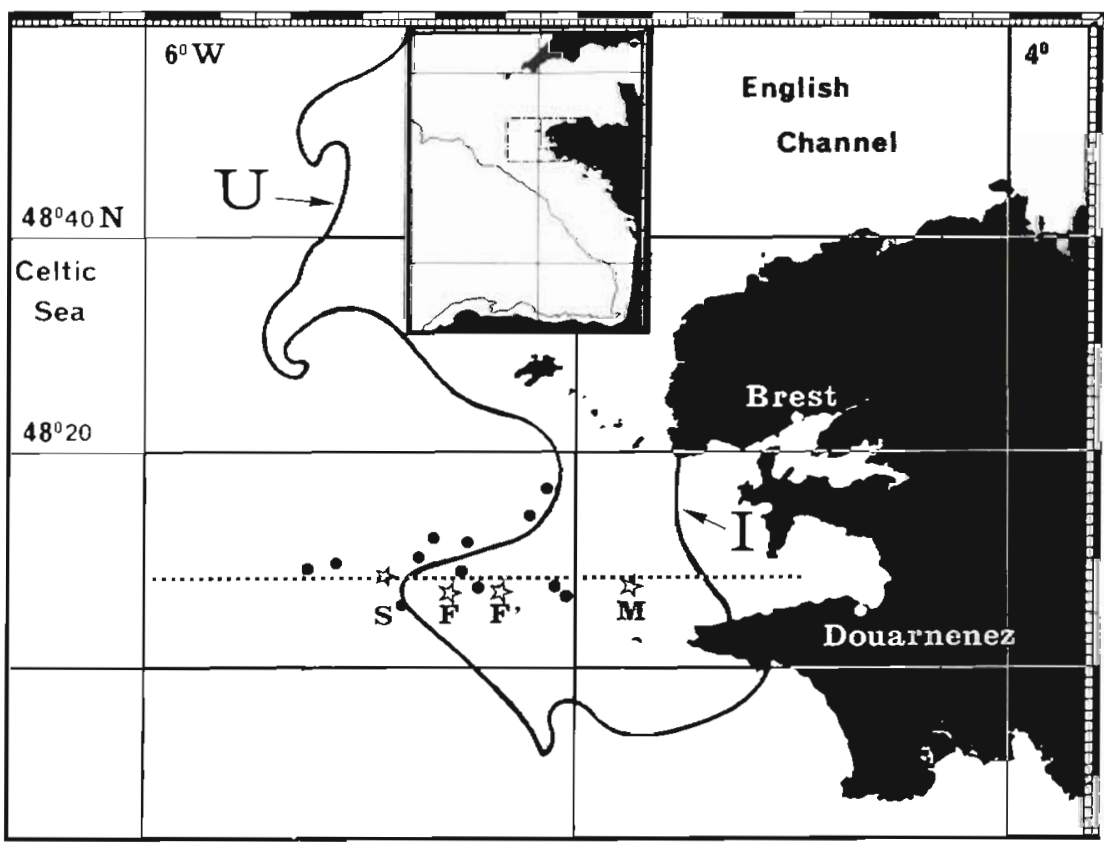

Fig. 1 Study area and mean position of the fronts (U: Ushant front; I: Iroise front) during 'Satir-Dynatlant' cruise. Dots: stations for primary production; open stars: reference points 
kinase (Sigma). All these measurements were made in triplicate on 2 parallel samples.

\section{RESULTS}

\section{Hydrographic features}

Fig. 2 shows temperature, nitrate and chlorophyll sections along the E-W transect $\left(48^{\circ} 08^{\prime}\right)$ on 18 to 19 September 1982 as an example of a typical structure. From the coast to the open sea, we can successively distinguish stratified coastal waters in the Bay of Douarnenez, colder mixed nutrient-rich waters $(3 \mu \mathrm{g}$ at $\mathrm{N}-\mathrm{NO}_{3} \mathrm{l}^{-1}$ ), separated from an offshore stratified zone by a high gradient of temperature and nutrients. In these frontal waters we did not observe high surface
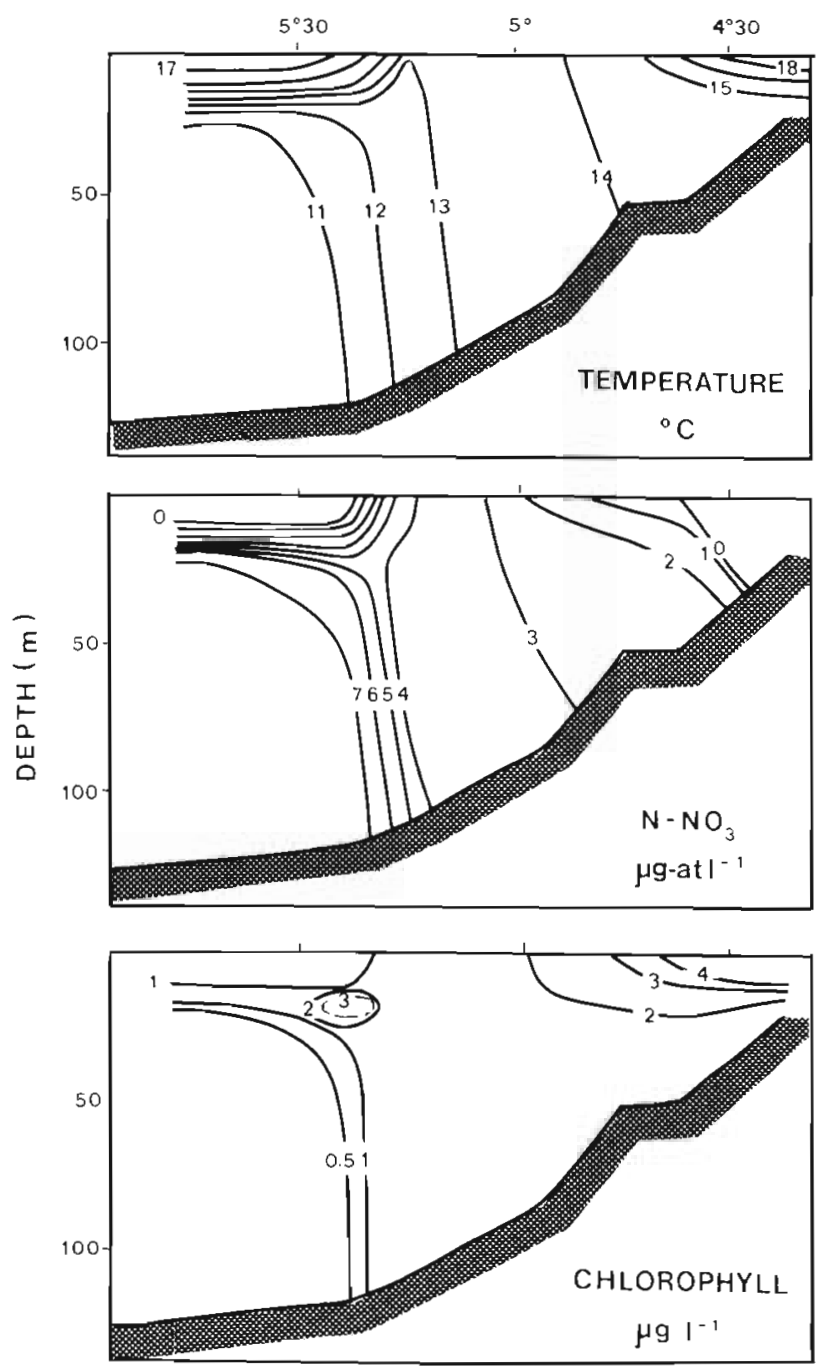

Fig. 2. Temperature, nitrate and chlorophyll a sections across the southern part of the Ushant front at spring tide (18-19 Sep 1982). Data from Morin (unpubl.) chlorophyll values but only a slight maximum on the thermocline.

The position of the tidal front is greatly influenced by the tidal cycle: at spring tides, strong tidal currents cause a maximum extent of the mixed area. Consequently, the reference points $M, F$ and similar stations showed a variable thermal structure depending on the fortnightly tidal cycle with maximum stability at neap tides.

The semi-diurnal tidal cycle also imposes variations of the thermal structure on the water masses with maximum mixing in frontal and cold waters at high tide. Hence, the present results refer mainly to the vertical temperature profiles. Typically stratified and frontal waters have been defined by surface temperatures respectively higher than $16^{\circ} \mathrm{C}$ and close to $15^{\circ} \mathrm{C}$. In the mixed waters, surface temperature was near $14^{\circ} \mathrm{C}$.

\section{Vertical profiles}

In stratified waters, the strong thermal stratification $\left(\Delta T=5 C^{\circ}\right)$ was associated with a sharp nitracline and total nutrient depletion in the upper layers above the thermocline (Fig. 3a, b). Although the physical and chemical parameters were relatively constant, chlorophyll biomass showed a different distribution at different stations: either a strong maximum up to $3.5 \mu \mathrm{g} \mathrm{Chl} \mathrm{a} \mathrm{l}^{-1}$ above the thermocline at high tide or a nearly homogenous distribution with low values $\left(<1 \mu \mathrm{g} \mathrm{Chl} \mathrm{a} 1^{-1}\right)$ at low tide $\left(\Delta \mathrm{T}=3.5 \mathrm{C}^{\circ}\right)$ was observed. But, regardless of station and light level primary production did not exceed $7 \mu \mathrm{g} \mathrm{C} \mathrm{l}^{-1} \mathrm{~h}^{-1}$.

In mixed waters, at the time of low tide (Fig. 3c), vertical profiles showed the characteristics of stratified layers (thermocline, nitracline, low production $<5 \mu \mathrm{g}$ $\mathrm{C}^{-1} \mathrm{~h}^{-1}$ ) although chlorophyll values were higher than offshore over the whole water column of the euphotic zone. Conversely, when the water masses were well mixed by the tidal current, temperature was homogeneous, nitrate was high, chlorophyll biomass was greater than $1.5 \mu \mathrm{g} \mathrm{I}^{-1}$ in the whole column, and primary production was high (up to $20 \mu \mathrm{g} \mathrm{Cl}^{-1} \mathrm{~h}^{-1}$ ) (Fig. 3d).

In frontal waters, as mentioned previously, the thermal structure was closely related to the tidal cycle. Whether a fixed point (temporal variations) or a transect (spatial variations) is followed, we successively meet: (1) a warm stratified water mass (Fig. 3e) showing the same features as Point $S_{;}(2)$ the front itself (Fig. 3f) with a weaker thermal gradient $\left(\Delta \mathrm{T}=3 \mathrm{C}^{\circ}\right)$, a weaker nitracline, the surface layer being not quite nutrient-depleted $\left(\mathrm{NO}_{3}-\mathrm{N}>0.2 \mu \mathrm{g}\right.$-at $\left.\mathrm{l}^{-1}\right)$, and chlorophyll biomass higher than $3 \mu \mathrm{g} \mathrm{Chl} \mathrm{a} \mathrm{l}^{-1}$ being highly productive $\left(15 \mu \mathrm{g} \mathrm{Cl}^{-1} \mathrm{~h}^{-1}\right)$ at the surface; and 

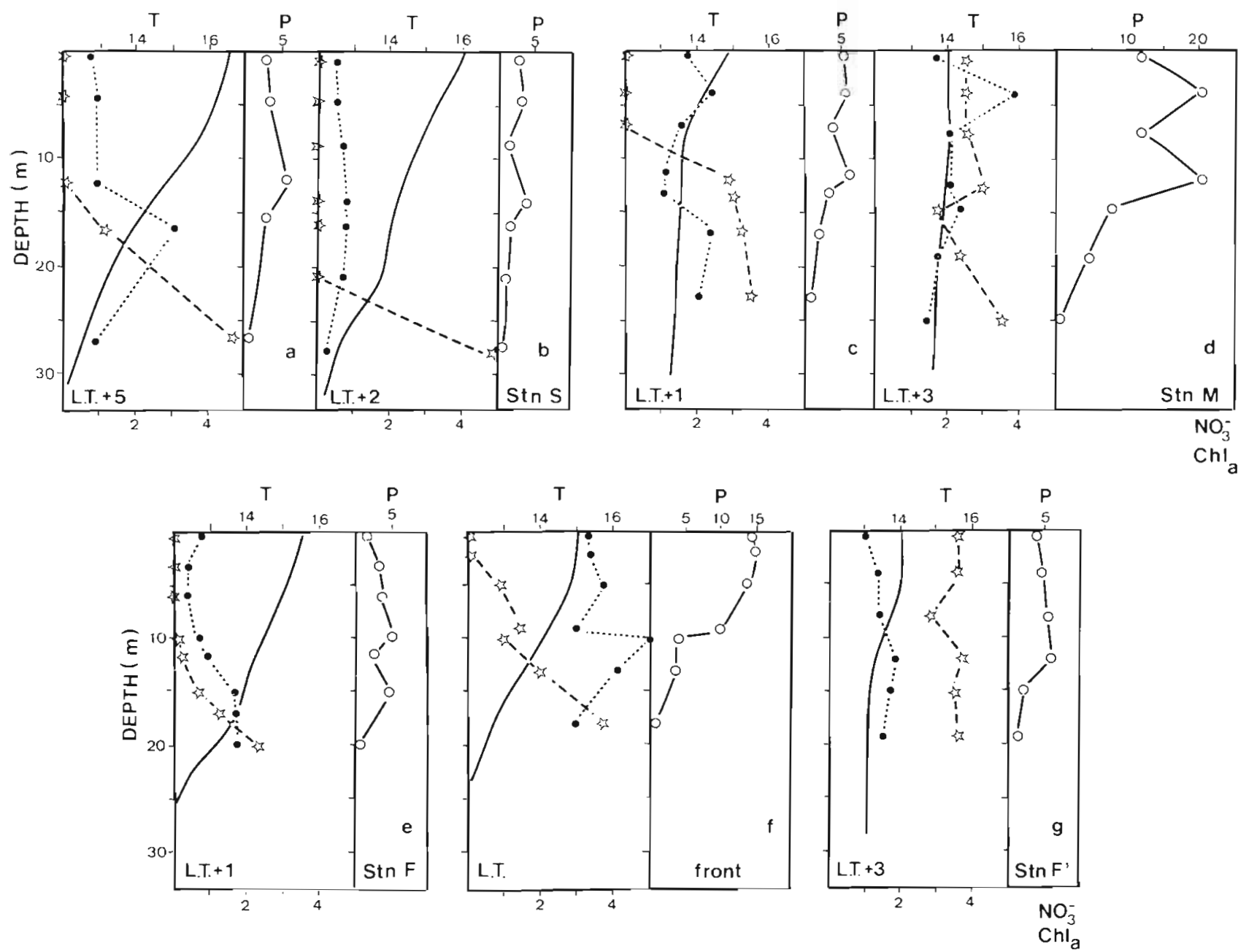

Fig. 3. Vertical distributions of (-) temperature, (....) chlorophyll a and (- - -) nitrate in the euphotic water column in relation to time of low tide (L.T.) at the reference points. Top axis: temperature ( $\mathrm{T}^{\circ} \mathrm{C}$ ) and production $\mathrm{P}$ ( $u g \mathrm{Cl}^{-1} \mathrm{~h}^{-1}$ ); bottom axis: nitrate $\left(\mu \mathrm{g}\right.$-at $\left.\mathrm{l}^{-1}\right)$ and chlorophyll a $\left(\mu \mathrm{g} \mathrm{l}^{-1}\right)$. All measurements were made at spring tide

(3) a colder water layer (Fig. 3g) with abundant nutrients $\left(\mathrm{NO}_{3}-\mathrm{N}>3 \mu \mathrm{g}\right.$-at $\left.\mathrm{l}^{-1}\right)$ but less chlorophyll (1 to $2 \mu \mathrm{g} \mathrm{Chl} \mathrm{a} \mathrm{l}^{-1}$ ) and lower production $\left(<7 \mu \mathrm{g} \mathrm{C} \mathrm{l}^{-1}\right.$ $\mathrm{h}^{-1}$ ) than expected for such a nutrient-rich water mass.

\section{Daily production}

Taking into account these different features, mean daily production and other associated properties were evaluated for each region (Table 1). Production rates increased from the open sea $\left(0.885 \mathrm{~g} \mathrm{C} \mathrm{m}^{-2} \mathrm{~d}^{-1}\right)$ to the frontal zone $\left(1.66 \mathrm{~g} \mathrm{C} \mathrm{m}^{-2} \mathrm{~d}^{-1}\right)$ with highest values on the front itself $\left(1.8 \mathrm{~g} \mathrm{C} \mathrm{m}^{-2} \mathrm{~d}^{-1}\right)$; chlorophyll content exhibited the same trend. Conversely, the mean and maximum assimilation numbers decreased from the open sea ( $8.3 \mathrm{mg} \mathrm{C}$ [ $\mathrm{mg} \mathrm{Chl} a]^{-1} \mathrm{~h}^{-1}$ ) to the frontal region (4.4 mg C [mg Chl a $]^{-1} \mathrm{~h}^{-1}$ ). Because the front moved, only one sampling was carried out in typical mixed water where daily production and assimilation number were very high, respectively 3 and 2 times the values obtained in the frontal zone on the mixed side. The latter showed composite characteristics of stratified (biomass, production), frontal (assimilation numbers), and mixed waters (nutrient values, photic depth).

For this period (spring tide) no water mass of any type was totally nutrient depleted (Table 1). In offshore and frontal waters, mean nitrogen values as nitrates were higher than $1 \mu \mathrm{g}$-at $1^{-1}$ at the maximum biomass level, which was generally located well above the euphotic limit.

\section{Production and productivity}

Over the whole area, daily production appears to be proportional to chlorophyll values of the euphotic 
Table 1. Daily production and main associated properties in the various regions of the Ushant front area with standard deviation and sample number in parentheses

\begin{tabular}{|c|c|c|c|c|c|}
\hline \multirow[t]{2}{*}{ Parameter } & \multirow[t]{2}{*}{ Stratified } & \multicolumn{3}{|c|}{ Transitional } & \multirow[t]{2}{*}{ Mixed } \\
\hline & & Stratified side & Frontal & Mixed side & \\
\hline Daily production $\left(\mathrm{gC} \mathrm{m}^{-2} \mathrm{~d}^{-1}\right)$ & $\begin{array}{c}0.885 \pm 0.287 \\
(6)\end{array}$ & $0.982 \pm 0.211$ & $\begin{array}{c}1.66 \pm 0.171 \\
(4)\end{array}$ & $\begin{array}{c}1.04 \pm 0.237 \\
(6)\end{array}$ & $\begin{array}{l}3.5 \\
(1)\end{array}$ \\
\hline Biomass (mg Chl a m²) & $33.45 \pm 17.08$ & $27.65 \pm 7.29$ & $\begin{array}{c}61.77 \pm 21.62 \\
\text { (4) }\end{array}$ & $\begin{array}{c}34.87 \pm 7.812 \\
(6)\end{array}$ & $\begin{array}{l}53 \\
(1)\end{array}$ \\
\hline Solar radiation $\left(\mathrm{MJ} \mathrm{m}^{-2} \mathrm{~d}^{-1}\right)$ & $\begin{array}{c}14.66 \pm 3.53 \\
(6)\end{array}$ & $14.40 \pm 3.97$ & $\begin{array}{c}10.30 \pm 3.25 \\
(6)\end{array}$ & $\begin{array}{c}12.90 \pm 4.96 \\
(6)\end{array}$ & $\begin{array}{l}3.0 \\
(1)\end{array}$ \\
\hline \multicolumn{6}{|l|}{$\begin{array}{l}\text { Assimilation number } \\
\qquad\left(\mathrm{mg} \mathrm{C}[\mathrm{mg} \mathrm{Chl} a]^{-1} \mathrm{~h}^{-1}\right)\end{array}$} \\
\hline Maximum & $\begin{array}{c}8.30 \pm 4.34 \\
(6)\end{array}$ & $\begin{array}{c}5.93 \pm 2.28 \\
(6)\end{array}$ & $4.46 \pm 1.44$ & $\begin{array}{c}4.36 \pm 1.85 \\
(6)\end{array}$ & $\begin{array}{r}10.7 \\
(1)\end{array}$ \\
\hline Mean & $\begin{array}{c}3.78 \pm 3.41 \\
(37)\end{array}$ & $\begin{array}{c}3.36 \pm 2.26 \\
(21)\end{array}$ & $\begin{array}{c}2.24 \pm 1.60 \\
(25)\end{array}$ & $\begin{array}{c}2.40 \pm 1.53 \\
(33)\end{array}$ & $5.13 \pm 2.97$ \\
\hline $\mathrm{N}-\mathrm{NO}_{3}\left(\mathrm{mg}\right.$-at $\left.\mathrm{m}^{-2}\right)$ & $42.73 \pm 21.40$ & $8.28 \pm 4.25$ & $36.61 \pm 36.58$ & $\begin{array}{c}62.10 \pm 26.38 \\
(3)\end{array}$ & $\begin{array}{l}65.37 \\
(1)\end{array}$ \\
\hline $\begin{array}{l}\mathrm{N}-\mathrm{NO}_{3} \text { at biomass maximum } \\
\left(\mu \mathrm{g} \text {-at } l^{-1}\right)\end{array}$ & $1.75 \pm 1.50$ & $\begin{array}{c}1.26 \pm 0.99 \\
(7)\end{array}$ & $1.64 \pm 1.43$ & - & - \\
\hline
\end{tabular}

zone, except for one station located in the mixed zone which is clearly more productive. We considered 3 series of productivity values (or assimilation numbers) (mg C $[\mathrm{mg} \mathrm{Chl} \mathrm{a}]^{-1} \mathrm{~h}^{-1}$ ) depending on the light level $(100 \%$ light surface intensity was excluded because of possible photoinhibition) (Fig. 4). For light levels of 7 and $3 \%$ of surface light intensity (Fig. 4B) and for the $1 \%$ level (Fig. 4C), values from the stratified and intermediary areas, all stations considered, were negatively correlated to chlorophyll biomass. For subsurface samples (50 to $10 \%$ light surface intensity), 2 sets of results were obtained. Most values corresponding to stratified and frontal zones were negatively correlated with a high degree of significance ( $p=0.99$ ) (Fig. 4A). However, productivity on the front itself was comparatively so high with respect to chlorophyll content that 7 relevant points have not been included in the regression. From the general regression, predicted productivity values plotted against the observed values show that the productivity on the front could be double that forecasted (Fig. 5), especially in the upper layer.

\section{Phytoplankton composition}

Phytoplankton composition varied in relation to the hydrological structure. At neap tides (Fig. 6A), nanoflagellates - mainly Cryptophyceae - were dominant over the whole area, surface coastal waters excepted. At spring tides (Fig. 6B), diatoms were well represented not only in the mixed waters but also even in the stratified transitional waters, and were as abundant at the surface as on the thermocline. The pennate diatom Nitzschia seriata was the dominant species

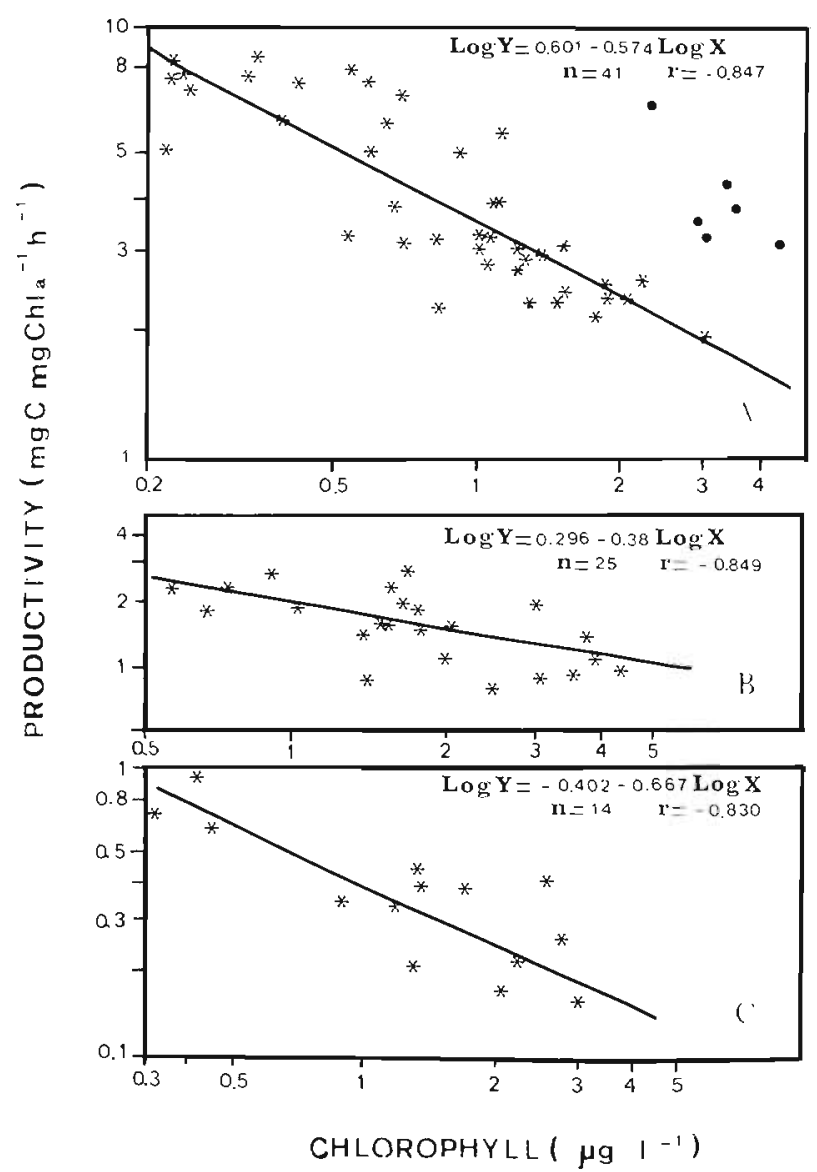

Fig. 4. Productivity as a function of the chlorophyll biomass for different light levels in stratified and transitional waters. (A) Subsurface samples (50 to $10 \%$ light surface level). Dots corresponding to front stations were not included in the regression line. (B) Samples from 7 and $3 \%$ surface light level. (C) Samples from $1 \%$ surface light level. Note the change of scales 


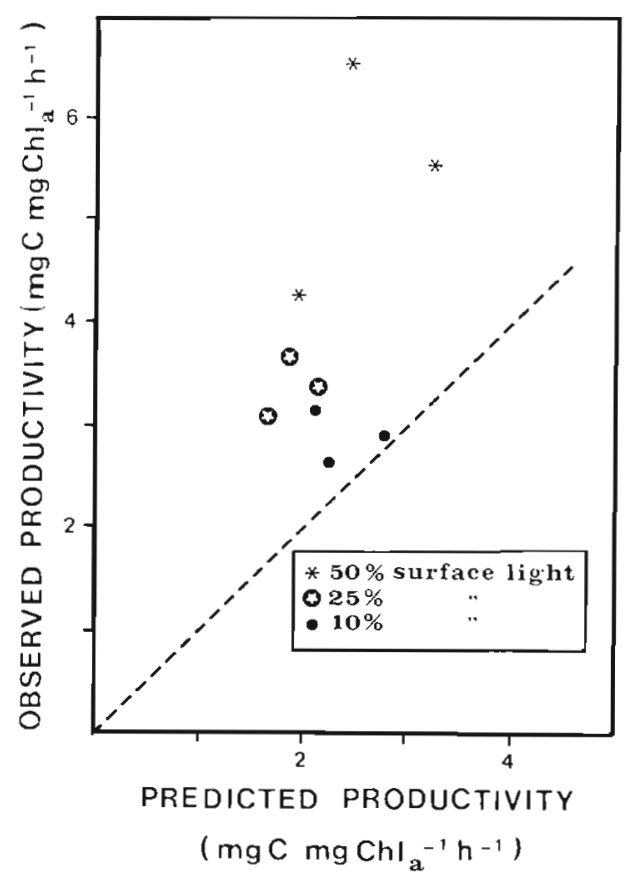

Fig. 5. Productivity in the upper layers close to the Ushant front as compared to the predicted values from regression equation (see Fig. 4A)
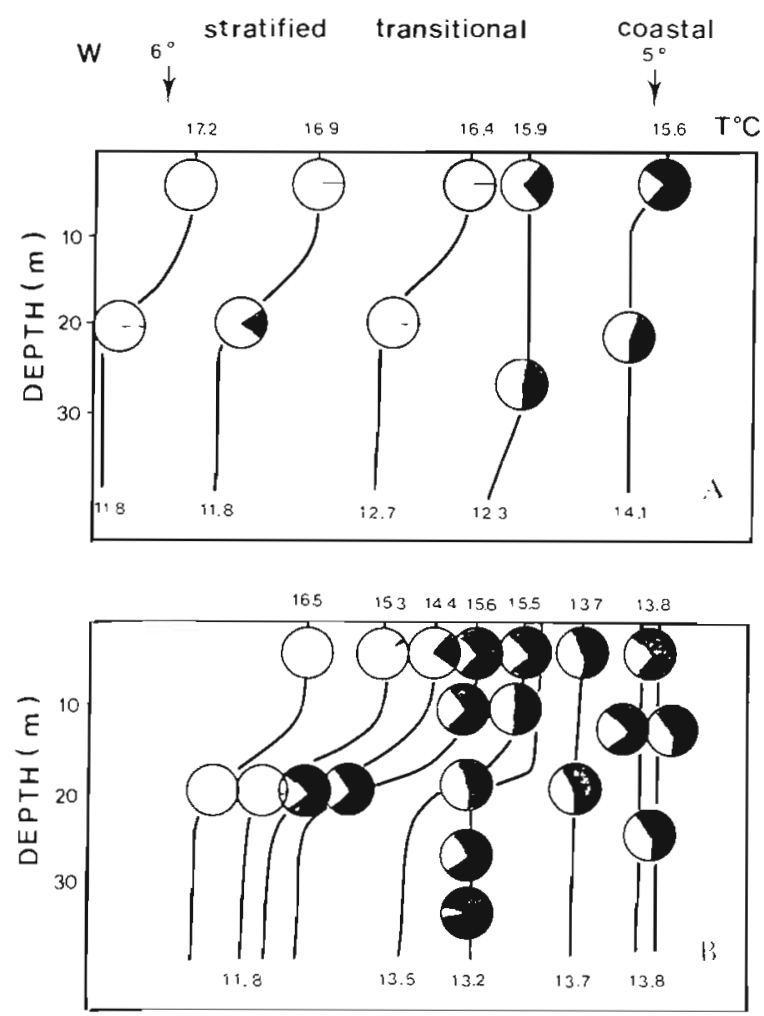

Fig. 6. Distribution of phytoplankton in relation to tide: (A) neap tide; (B) spring tide. Nanoflagellates (white) and diatoms (dark) are expressed as percent of total cell counts (from cell counts communicated by Vigier $C$. and MartinJézéquel $V$.) among various Rhizosolenia and Chaetoceros spp. At this time, nanoflagellates were dominant only in the well-stratified waters. Dinoflagellates were poorly represented $\left(<4000\right.$ cell $\left.1^{-1}\right)$ by various Peridiniaceae, Prorocentraceae and Dinophysaceae.

\section{Light adaptation}

The light saturation curves of the stratified-water samples (frontal and oceanic) were different depending on the light level (Fig. 7). The deepest populations of the oceanic stratified zone showed a high photoinhibition for light intensity higher than $250 \mu \mathrm{E} \mathrm{m} \mathrm{m}^{-2}$ $\mathrm{s}^{-1}$ while the subsurface phytoplankton was better adapted to high light level. This light adaptation did not appear in the subsurface samples of the stratified frontal zone which had furthermore a higher $\mathrm{P}_{\mathrm{m}}^{\mathrm{B}}$ (maximum productivity).

In the transitional or more coastal 'mixed' waters, the photosynthetic properties of surface and deep populations were quite different, indicating a further surface stability as shown by the photosynthesis-irradiance curves of the subsurface samples. These exhibited an extended plateau for light intensities from about 500 to $2000 \mu \mathrm{E} \mathrm{m}^{-2} \mathrm{~s}^{-1}$. A paradoxical phenomenon was observed for the frontal populations (Point $F^{\prime}$ ), which appeared to be more light adapted with increasing depth. In all cases, $\mathrm{P}_{\mathrm{m}}^{\mathrm{B}}$ and $\alpha$, the slope of the curve at low light intensities, were lower than those in the stratified-water populations.

\section{Adenylate energy charge}

Over the whole area, AEC was generally high (Table 2 ) with maximal values $(>0.8)$ in the subsurface layers of the stratified frontal zone and minimal values in the thermocline populations of the stratified oceanic waters (0.5). The vertical profiles showed different features according to the water column studied.

In stratified nutrient-deplete waters where nanoflagellates were the only phytoplankton cells, AEC was high in the upper layers but decreased at depth (Point S). At the time of sampling, diatoms were dominant in frontal and mixed coastal zones. On the stratified side of the frontal region (Point F) a double influence of light level and nutrient concentrations could be observed. In the nutrient-deplete surface layer, AEC values roughly decreased with light down to a critical value of 0.47 . Then they increased, just above the nitracline, with increasing nutrient concentration in spite of the low light level. In contrast, on the mixed side of the transitional zone (Point F') the medium was not nutrient-depleted and $\mathrm{AEC}$ was high 
in the upper layers and then fell where the light level was $<10 \%$ of surface. In homogeneous, nutrient-rich waters (Point $\mathrm{M}$ ), AEC was roughly constant throughout the water column.

\section{ATP and chlorophyll $a$}

ATP values can be used as a measure of living biomass, and be related to pigment concentration by means of regression analysis. For all values $(n=23)$ and with ATP and Chl a expressed as $\mu \mathrm{g} \mathrm{l}^{-1}$ :

$\mathrm{ATP}=0.202 \mathrm{Chl} a-0.019 \quad \mathrm{r}=0.788 \quad \mathrm{p}=0.99$

However, a more detailed study revealed that only values $(\mathrm{n}=9$ ) from surface samples $(<7 \mathrm{~m})$ had a good correlation

$\mathrm{ATP}=0.262 \mathrm{Chl} a-0.0072 \quad \mathrm{r}=0.936 \quad \mathrm{p}=0.99$

The low value of the $y$-axis intercept and the high coefficient of correlation indicate that the chlorophyll values were well representative of the living standing crop, in contrast to the chlorophyll content of the deepest populations which has a poor relation $(\mathrm{r}=0.517$; $\mathrm{n}=14 ; \mathrm{p}<0.95)$ to ATP concentration. The Chl $a:$ ATP ratio was not constant but higher at the low light level ( 2 or 3 times surface values; Table 2) and could indicate either an increase of pigment production per unit biomass as an adaptation to low light levels (Paerl et al. 1976, Falkowski \& Owens 1980) or a response to nutrient deficiency (Perry 1976, Romano 1976). In order to resolve this question, the cellular carbon to chlorophyll ratio could be analyzed in relation to depth.

\section{POC : Chl a ratios}

The relationship of particulate organic carbon to chlorophyll a (POC:Chl a) was studied as follows. From the data of Moal et al. (1985), POC: Chl a ratios were determined by regression analysis. Data were grouped in space (hydrological structure) and time (spring-neap tide) to avoid some bias (Banse 1977). Consequently, in typical stratified and mixed waters, there was not enough data to estimate this ratio. However over the whole water mass of the transitional area, regression analysis gives a POC: Chl a ratio of 45.5 with a high coefficient of correlation but, like ATP concentrations, 2 sets of data depending on the sampling depth could be observed (Fig. 8). In the upper layer $(<7 \mathrm{~m})$, regression analysis yields a POC: Chl a ratio of 92 , in the same range as that found by Holligan et al. (1984a) in stratified and frontal regions (81 and 74, respectively). Such high values may indicate nitrate-poor water (Eppley 1968). By contrast, the

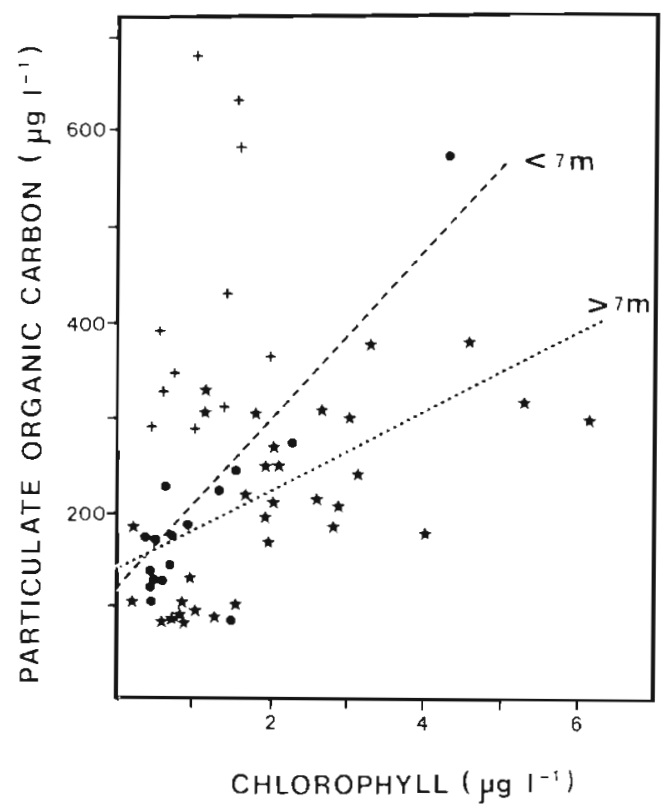

Fig. 8. Standing stocks of particulate organic carbon (particle size $<200 \mu \mathrm{m}$ ) and chlorophyll $a$ in the euphotic layer of transitional water column. Data from Moal et al. (1985). Regression equations give for depths $<7 \mathrm{~m}$ (dots): $\mathrm{POC}=$ 92.64 Chl $a+113.67(\mathrm{n}=20 ; \mathrm{r}=0.774 ; \mathrm{p}=0.99)$ and for depths $>7 \mathrm{~m}$ (stars): $\mathrm{POC}=38.34 \mathrm{Chl} a+145.05(\mathrm{n}=37$; $r=0.498 ; p=0.99$ ) Crosses represent samples from frontal stations (not included in the regression line)

POC : Chl a ratio falls to 38 in the deepest layers, equal to the value obtained by Lorenzen (1968) in upwelling areas. These different values are in good agreement with those used by Estrada (1985) in Mediterranean and tropical waters. Consequently, the increase in the Chl a: ATP ratio appears to be related to shade adaptation rather than nutrient deficiency. Ten plots corresponding to the front were not included in these regression lines. At all depths, the POC: Chl a ratio is higher over the whole front but no relationship was observed between carbon and chlorophyll. These high carbon concentrations are likely due to a higher detritic and/ or heterotrophic biomass.

From the different $\mathrm{POC}$ : Chl a ratios in relation to depth, the carbon content of samples collected for ATP measurements was calculated (Table 2). The regression line obtained from these values $(n=16)$ gives the following relation (POC and ATP concentrations expressed as $\mu \mathrm{g}^{-1}$ ):

$\mathrm{POC}=274.7 \mathrm{ATP}+15.66 \quad \mathrm{I}=0.902 ; \quad \mathrm{p}=0.99$

This carbon-to-ATP ratio is higher than the usual value of 250 in oceanic waters (Holm-Hansen 1969) but quite near to the values obtained by Holm-Hansen (1970) or Berland et al. (1972) from batch cultures of various groups of phytoplankton (ATP $=0.35$ and 
$0.32 \%$ POC, respectively) or Pearl \& Williams (1976) in thermally stratified lakes ( $\mathrm{POC}=276 \mathrm{ATP}$ ).

\section{Growth rates}

Specific growth rates of the diatom populations were estimated where they were dominant, i.e. over the whole transitional area, as follows

$$
\mu\left(\mathrm{d}^{-1}\right)=\ln \frac{\mathrm{POC}+\Delta \mathrm{C}}{\mathrm{POC}}
$$

with $\triangle \mathrm{C}$ calculated from the ${ }^{14} \mathrm{C}$ fixation of phytoplankton. In situ growth rates showed great variability over the transitional area and through the water column but they were always highest in the subsurface layer ( 8 to $12 \mathrm{~m}$ ) (Table 2 ). In order to estimate the light influence, the maximal growth rate was calculated from light-saturated photosynthesis. At each station, in the upper layers (>10\% light surface level) the in situ growth rate was maximal, while the in situ growth rates of the deepest populations were clearly lower. On the other hand, the maximal growth rates at the $1 \%$ light surface level were always higher than the maximal growth of the subsurface phytoplankton, particularly at Point $F^{\prime}$ where even the in situ growth was faster. Over the whole transitional area, higher specific growth rates were found at Point $F$, on the stratified side, for the $10 \%$ surface light intensity, as also at point $\mathrm{M}$ in the mixed waters.

\section{DISCUSSION AND CONCLUSIONS}

The greatest part of the study area was in the transitional zone. Because of the proximity of a main shipway in the west, the mooring of Reference Point $\mathrm{S}$, usually located at $6^{\circ} \mathrm{W}$, had to be moved towards the front. Consequently, on spring high tides hydrological characteristics here were identical to frontal waters. On the other hand, the area of Point $\mathrm{M}$, close to both the Ushant and the Iroise fronts, was greatly influenced by the fronts. Therefore, at neap tides, the water column was slightly stratified.

As previously observed in other frontal areas an increase of pigment content in the euphotic water column was observed from the open sea to the frontal boundary. Daily production increased in the same way even on the front itself while lower values of the assimilation number were observed. The decrease of the latter can be explained by a self-shading phenomenon related to the greater cell size and higher chlorophyll content of the diatom populations. Consequently, the densest and/or most pigmented phytoplankton was relatively less productive than chlorophyll-poor popu- lations, as shown by constructing reference lines (Fig. 4).

However, the physiological state of the various populations was not constant over the transitional zone. All the tests were carried out on spring tide and therefore concerned either nanoflagellate populations in the well-stratified waters or diatom populations (Nitzschia seriata) in the entire remaining zone, front included. Dinophyceae were poorly represented.

All the properties measured at Point $S$ show the influence of water stabilization (related to the previous neap tide) on the chemical state of the Cryptophyceae. The low Chl a: ATP ratio appears to be independent of the light level and consequently shows nutrient depletion prevailing in all the populations. Photosynthesisirradiance curves indicate a difference in light adaptation between surface populations well adapted to high light regime and their shade-adapted counterparts on the thermocline. However, the values of the photosynthetic properties $\mathrm{P}_{\mathrm{m}}^{\mathrm{B}}$ and $\alpha$ of the latter were higher than at the surface, which could suggest either surface nutrient depletion or thermal stress related to incubation $\left(\Delta T=4 C^{\circ}\right)$ as described by Falkowski (1980, p. 115).

Specific growth rate, particularly for the in situ measurements, was relatively low for such small cells. The physiological activity of the nanoflagellates appeared to be mainly influenced by light intensity as shown by the decrease of AEC from the surface to low light levels.

In the transitional zone, the surface populations of diatoms seem, physiologically, quite different from the deepest. In the latter, over the whole zone, the low POC : Chl a ratio indicates that cells were not nutrient depleted. At the same time, the maximum potential growth rate increased up to $1 \mathrm{~d}^{-1}$, especially in the biomass maximum of the stratified frontal region. On this side, in spite of the surface nutrient depletion, $\mathrm{P}_{\mathrm{m}}^{\mathrm{B}}$, $A E C$, and in situ grow th rates appear to be highest in the upper $10 \mathrm{~m}$. Although the photosynthetic properties suggest a different light adaptation in surface and thermocline cells, the photosynthesis-irradiance curves are quite similar, without a plateau in the surface samples. The weak adaptation of these cells to high light level indicates a shorter dwelling time in the upper layer, as a consequence of the decreased spring tide stability. Special attention should be paid to the $10 \%$ light level population which appears to be in optimal conditions of illumination and nutrient supply as shown by the high values of the physiological properties, more particularly the in situ growth rate which equals the maximal one. In the deepest layers, the cells are light limited but the input of nutrients from below the thermocline, altered by the strong spring tide current, involves a high potential activity. 
Although no experiment was carried out upon front populations, an enhancement of productivity was observed (Fig. 5) in the upper layers of the water column.

Paradoxically, on the mixed side of the study area (Point $M)$, the slight surface stabilization $(\Delta \mathrm{T}=$ $0.07 \mathrm{C}^{\circ}$ ) is associated with a subsurface maximum of biomass isolated from the deepest layers. Thus, the light adaptation of the cells is very strong as shown by the extended plateau of the productivity curve (Fig. 7). In spite of the nitrate enrichment in the whole water column, only the $10 \%$ light level population exhibits high in situ assimilation number and specific growth rate. Due to the increase of productivity at this light level and of production related to the biornass maximum, the water mass is more productive than in neighbouring stations. However, a still more complex situation can be met as shown by the results obtained a fortnight later, at the start of the following spring tide (Point $F^{\prime}$ ). At this time, the profiles of temperature and nutrient and chlorophyll contents were typical of wellmixed waters. The Chla:ATP ratios in the whole water column increased. This ratio and the other chemical properties, as they vary with depth, reveal that the water body is not truly homogeneous or, at least, is just becoming mixed.

More difficult to understand are the photosynthesisirradiance curves at Point $F^{\prime}$. The photosynthetic properties are not only all inverted, but also substantiate strong light adaptation as if the deepest populations had come from a stabilized surface layer. An experimental error is unlikely because the in situ productivity $\mathrm{P}^{\mathrm{B}}$ is equivalent to the $\mathrm{P}^{\mathrm{B}}$ measured on the photosynthesis curve for a given light level. Furthermore, similar results were obtained in later studies (unpubl. data). Because of the lack of wind and the low increase of the tidal current, the only explanation could be a convergence movement as described by Simpson (1981), where the circulation velocity must be higher than the light adaptation rate of the cells. From Falkowski's model (1983), by using the surface and $1 \%$ light level $\mathrm{P}_{\mathrm{m}}^{\mathrm{B}}$ ratios, an approximate value of 0.007 $\mathrm{cm} \mathrm{s}^{-1}$ was estimated for phytoplankton displacement in the euphotic zone. Despite lower energy charge (which can suggest light stress), specific growth rate at low light level remains high, especially in situ where it is even the greatest rate measured. However, because of the low $\mathrm{P}_{\mathrm{m}}^{B}$ in the upper layers, the whole water column in such a disturbed system is much less productive than the neighbouring frontal zones.

It can be concluded, however, that over the whole frontal system, diatoms can grow whatever the hydrological structure. On the stratified side of the transitional zone, where the biological activity of the cells has been questioned (Le Fèvre et al. 1983, Holligan et al. 1984b, Richardson et al. 1985), we have revealed, at least in this case (spring tide; diatorns), that the physiological state of the cells is improved as shown by the high specific growth rates, more particularly in surface waters. Furthermore, the extent of diatoms over the stratified side of the frontal zone can be interpreted as evidence for the cross-frontal transfer suggested by Pingree (1978).

Acknowledgements. I am grateful to GREPMA (Groupe Régional d'Etude Pélagique en Manche), particularly to P. Le Corre, for the opportunity to realize this work. I thank A. Sournia and anonymous reviewers for their critical reading, J. L. Birrien for nutrient and chlorophyll measurements, C. Vigier and V Martin-Jézéquel for cell counts and IFREMER for ship time allocation.

\section{LITERATURE CITED}

Atkinson, D. E., Walton, G. M. (1967). Adenosine triphosphate conservation in metabolic regulation. J. biol. Chem. 232: 3239-3241

Banse, K. (1977). Determining the carbon-to-chlorophyll ratio of natural phytoplankton. Mar. Biol. 41: 199-212

Berland, B., Bonin, D. J., Laborde, P. L., Maestrini, S. Y. (1972). Variations de quelques facteurs estimatifs de la biomasse et en particulier de l'ATP chez plusieurs algues marines planctoniques. Mar. Biol. 13: 338-345

Eppley, R. W. (1968). An incubation method for estimating the carbon content of phytoplankton in natural samples. Limnol. Oceanogr. 13: 574-582

Estrada, M. (1985). Primary production at the deep chlorophyll maximum in the western Mediterranean. In: Gibbs, P. E. (ed.) Proceedings of the nineteenth European Marine Biology Symposium. Cambridge University Press, Cambridge, p. $109-122$

Falkowski, P. G. (1980). Light-shade adaptation in marine phytoplankton. In: Falkowski, P. (ed.) Primary productivity in the sea. Plenum Press, New York, p. 99-120

Falkowski, P. G. (1983). Light shade adaptation and vertical mixing of marine phytoplankton. A comparative field study. J. mar. Res. 41: 215-237

Falkowski, P. G., Owens, T. G. (1980). Light-shade adaptation: two strategies in marine phytoplankton. Pl. Physiol., Wash. 66: 592-595

Holligan, P. M. (1981). Biological implications of front on the northwest European continental shelf. Phil. Trans. R. Soc. 302: 547-562

Holligan, P. M., Harbour, D. S. (1977). The vertical distribution and succession of phytoplankton in the western English Channel in 1975 and 1976. J. mar biol. Ass. U.K. 57: 1075-1093

Holligan, P. M., Maddock, L., Dodge, S. D. (1980). The distribution of dinoflagellates around the British Isles in July 1977: a multivariate analysis. J. mar. biol. Ass. U.K. 60: $851-867$

Holligan, P. M., Harris, R. P., Newell, R. C., Harbour, D. S. Head. R. N., Linley, E. A. S., Lucas, M. I., Tranter, P. R. G. Weekley, C. M. (1984a). Vertical distribution and partitioning of organic carbon in mixed, frontal and stratified waters of the English Channel. Mar. Ecol. Prog. Ser. 14: $111-127$

Holligan, P. M., Williams, P. J., leB., Purdie, D., Harris, R. P. 
(1984b). Photosynthesis, respiration and nitrogen supply of plankton populations in stratified, frontal and tidally mixed shelf waters. Mar. Ecol. Prog. Ser. 17: 201-213

Holm-Hansen, O. (1969). Determination of microbial biomass in ocean profiles. Limnol. Oceanogr 14: 740-747

Holm-Hansen, O. (1970). ATP levels in algal cells as influenced by environmental conditions. Pl. Cell Physiol., Tokyo 11: 689-700

Karl, D. M., Holm-Hansen, O. (1978). ATP, ADP and AMP determinations in water samples and algal cultures. In: Hellebust, J. A., Craigie, J. S. (ed.) Handbook of phycological methods. II. Physiological and biochemical methods. Cambridge University Press, Cambridge, p. 198-205

Le Corre, P., Mariette, V. (1985). Le front thermique d'Ouessant en août et septembre 1982. Campagne SatirDynatlant. Campagnes Océanographiques Françaises, $N^{\circ} 1$ IFREMER, Brest

Le Fèvre, J. (1986). Aspects of the biology of frontal systems, Adv. mar. Biol. (in press)

Le Fèvre, J., Le Corre, P., Morin, P., Birrien, J. L. (1983). The pelagic ecosystem in frontal zones and other environments off the west coast of Brittany. Proceedings of the 17 th European Marine Biology Symposium. Oceanologica Acta vol. spéc.: $125-129$

Loder, J. W., Platt, T. (1985). Physical controls on phytoplankton production at tidal fronts. In: Gibbs, P. E. (ed.) Proceedings of the nineteenth European Marine Biology Symposium. Cambridge University Press, Cambridge, p. $3-22$

Lorenzen, C. J. (1968). Carbon/chlorophyll relationship in an upwelling area. Limnol. Oceanogr. 13: 202-204

Moal, J., Samain, J. F., Daniel, J. Y., Le Coz, J. R. (1985). Matériel particulaire. In: Le Corre, P., Mariette, V. (ed.) Le front thermique d'Ouessant en août et septembre 1982. Campagne Satir-Dynatlant. Campagnes Océanographiques Françaises, No 1. IFREMER, Brest, p. 185-202

Paerl, H. W., Williams, J. (1976). The relation between adenosine triphosphate and microbial biomass in diverse aquatic ecosystems. Int. Revue ges. Hydrobiol. 61 659-664

Paerl, H. W., Tilzer, M. M., Goldman, C. R. (1976). Chlorophyll a versus adenosine triphosphate as algal biomass indicators in lakes. J. Phycol. 12: 242-246

Perry, M. J. (1976). Phosphate utilization by an oceanic diatom in phosphorus-limited chemostat culture and in the oligotrophic waters of the central north Pacific. Limnol. Oceanogr. 21: 88-107

Pingree, R. D. (1978). Cyclonic eddies and cross frontal mixing. J. mar. biol. Ass. U.K. 58: 955-963

Pingree, R. D., Pugh, P. R., Holligan, P. M., Forster, G. R. (1975). Summer phytoplankton blooms and red tides along tidal fronts in the approaches to the English Channel. Nature, Lond. 258: 672-677

Richardson, K., Lavin-Peregrina, M. F., Mitchelson, E. G., Simpson, J. H. (1985). Seasonal distribution of chlorophyll $a$ in relation to physical structure in the western Irish Sea. Oceanologica Acta 8: 77-85

Romano, J. C. (1976). Contribution à l'étude de la phase de latence dans des cultures d'algues marines planctoniques. 2. Modification dans les rapports entre les pigments, les nucléotides adényliques et les acides ribonucléiques. C. r. Séanc. Soc. Bot. 170: 1069-1074

Simpson, J. H. (1981). The shelf-sea fronts: implication of their existence and behaviour. Phil. Trans. R. Soc. 302: 531-546 